\section{Costa Rican Pension System}

\section{Options for Reform}

\section{Aslı Demirgü̧̧-Kunt.}

Anita Schwarz

\author{
Costa Rica's demographic \\ structure is becoming \\ increasingly unfavorable, and \\ its pension system is \\ maturing, so reform of the \\ sacial security system should \\ be implemented without \\ delay. One option for \\ comprehensive reform is to \\ move toward a multipillar \\ system, with a basic pay-as- \\ you-go public pillar \\ complemented by a defined- \\ contribution savings pillar and \\ additional voluntary savings \\ schemes.
}

The World Bank

Policy Research Department

Finance and Private Sector Development Division

June 1995 


\section{Summary findings}

The Costa Rican Social Insurance Fund - the country's main social security institution - was established in 1941 to provide compulsory social insurance coverage for employees, through old-age, disability, and survivor pensions, as well as sickness and maternity benefits.

The current status of the pension system is alarming, and reform is urgently needed. Among other things:

- The system is costly to the government.

- It promises generous benefits that are difficult to sustain.

- Contribution rates are low.

- The link between contributions and benefits is weak.

- Inflation indexing is inadequate and ad hoc.
- Although there is no explicit early retirement system, individuals have found a substitute for early retirement in disability pensions.

- Health benefits to pensioners are paid out of pension contributions.

- The system's reserves have not been well invested.

Reform of the system should be immediate. At a minimum, reform should include:

- Reduced benefits.

- Higher contribution rates.

- A higher retirement age.

- A stronger link between contributions and benefits.

- The unbundling of health and pension accounts.

This paper - a product of the Finance and Private Sector Development Division, Policy Research Department - is part of a larger effort in the department to study old age security. Copies of the paper are available free from the World Bank, 1818 H Street NW, Washington, DC 20433. Please contact Paulina Sintim-Aboagye, room N9-057, extension 38526 (33 pages). June 1995 .

The Policy Research Working Paper Series disseminates the findings of work in progress to encourage the exchange of ideas about development issues. An objective of the series is to get the findings out quickly, even if the presentations are less than fully polishol. The papers carry the names of the authors and should be used and cited accordingly. The findings, interpretations, and conclusions are the authors' oun and should not be attributed to the World Bank, its Executive Board of Directors, or any of its member countries. 


\title{
COSTA RICAN PENSION SYSTEM: OPTIONS FOR REFORM
}

\author{
Aslı Demirgüç-Kunt and Anita Schwarz
}

The World Bank

The authors thank Tom Glaessner, Rosalinda Quintanilla and Salvador Valdes-Prieto for useful comments. 



\section{Introduction}

The Costa Rican Social Insurance Fund (CCSS), which is the main social security institution, was established in 1941 to provide compulsory social insurance coverage for employees on old-age, disability and survivor pensions as well as sickness-maternity benefits.

The pension system is fragmented, with 21 different schemes that have different rules and regulations, covering approximately 50 percent of the working population. CCSS covers 45 percent of the working population, insuring both public and private workers. Public workers that are not covered by CCSS, which amount to 5 percent of the working population, are covered by 19 special schemes which are independent from CCSS. The government's recent reforms aimed at combining the 17 special schemes (except the ones for teachers and judicial system) under a unified system.

The CCSS system is a partially funded defined benefit system based on scaled premiums. In these systems the contribution rate is set at a high enough level to create a reserve such that inflows of contributions and investment income from the reserve cover the pension expenditures and administrative costs during a given period. When the reserve income and contributions are no longer sufficent to cover the expenses, the contribution rate is raised to a higher level to ensure another period of equilibrium. ${ }^{3}$ These periods should be sufficiently long to ensure stability of contribution rates.

Scaled premium systems require periodic actuarial reviews to adjust the contribution rates to changes in the demographic structure, investment income of the fund, benefit levels, and growing maturity of the system. Many countries with scaled premium systems encounter problems, because actuarial reviews are delayed, overly generous benefits are promised, contribution rates remain low as the system matures, and reserves are not well invested. This is also the case in Costa Rica where actuarial reviews have only been required since 1990.

The following features of the Costa Rican pension system highlight the alarming situation and the need for urgent reform:

* It is very costly for the government. In 1994, over 12 percent of the budget will be spent on special schemes. An additional 3 percent is allocated to CCSS to partially cover the government's contribution. The government already owes 16,100 million colones of unpaid contributions to CCSS from previous years.

1 In Costa Rica, the changes are made on the retirement age rather than the contribution rate. The retirement age was originally set at 65 for both sexes to accumulate reserves. In 1980, it was lowered to 57 . In 1982 it was lowered to 55, only for women. In 1991, with increasing financial pressures, the retirement age increased to 61 and 1 month for men and 59 and 1 month for womer. Recently there was another increase of 10 months for both sexes. 
* It promises generous benefits with high targeted replacement rates which are very difficult to sustain in the long run. This is true for all schemes, and especially for special schemes since their benefits tend to be even more generous.

* Despite the generous benefits promised, it operates with low contribution rates which are again not sustainable in the long run. Low contribution rates from employees and employers coupled with high replacement rates require the government to make large contributions (especially in the case of the special schemes) which have become more and more difficult to fulfill.

* The system has a weak link between contributions and benefits. The minimum and maximum limits on pensions, basing the pensionable salary on the last five years, and other features make the pension system highly redistributive. The weak link between benefits and contributions leads to wide-spread evasion and under-reporting of salaries to avoid the pension contributions which are perceived as taxes on labor.

* Inflation indexation is inadequate and ad hoc. There is no adjustment for inflation in the calculation of the pensionable salary. Even after retirement the inflation adjustments of pensions and the minimum pension are not made regularly and only if there are available funds. This is how the system lowers the high promised replacement rates. However, this leads to perverse redistributions.

* Although there is no explicit early retirement system, individuals have found means to substitute disability pensions for an early retirement system. Due to generous benefits and lax regulations 30 percent of the pension expenditures go to disability pensions. Indeed, until 1992 there were more people getting disability pensions than there were old age pensioners.

* Health benefits to pensioners of CCSS are paid out of pension contributions. Approximately 10 percent of the expenses go to medical care. This further weakens the link between contributions and benefits. Keeping health and pension benefits together also exacerbates financial problems since as populations age health costs tend to increase at much higher rates than pension expenditures.

* The system's reserves have not been well invested. The investment in state bonds brought low returns. Until 1986 internal loans to sickness -maternity program were not good investments. More recently, CCSS and the Ministry of Finance have initiated plans to improve the investment performance of the pension system.

Since the demographic structure is becoming more unfavorable and the system is maturing, reforms of the social security system should be implemented without delay. A reform of the existing system should include a combination of measures such as reduction in benefits, increase in contribution rates, better inflation indexation of the benefits, increasing the retirement age, creating a stronger link between benefits and contributions, and unbundling health and pension accounts. A more comprehensive reform option is to move towards a multi-pillar system, with a basic pay-as-you-go redistributive public pillar complemented by a defined contribution savings pillar and additional voluntary savings schemes. (See Box 1 for a discussion of a multi-pillar pension system.) 
The paper is organized as follows. Section II describes the present system and highlights its problems. Section III illustrates the fiscal cost of the present system within the framework of a simulation model. Section IV describes and evaluates different reform options and concludes with recommendations for reform.

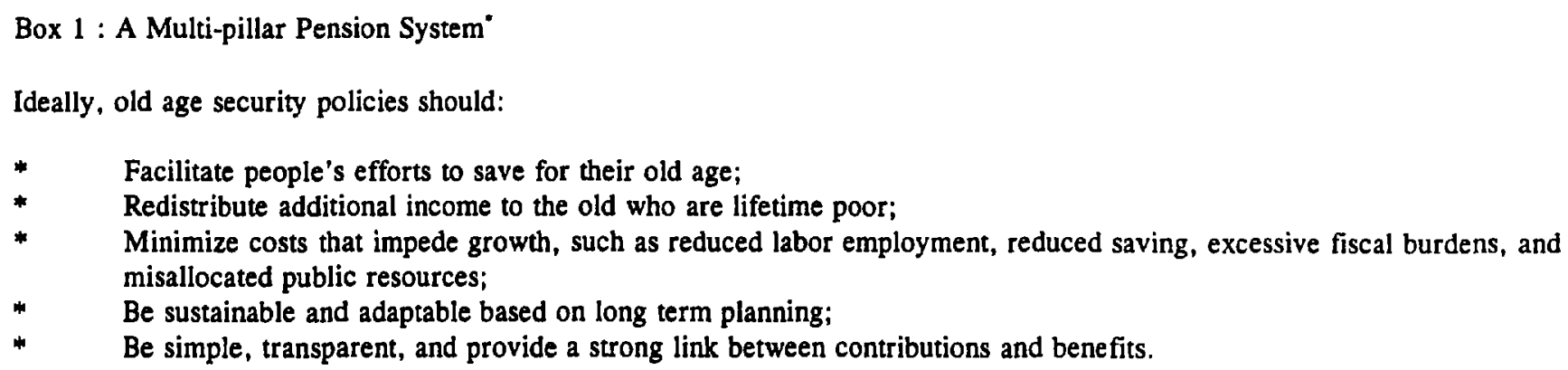

One of the prime policy issues to be resolved in the design of old age security programs is the relative importance of the redistribution, saving and insurance functions and the role of government in each. One way of achieving multiple objectives at least cost to society is through a multi-pillar approach:

1. Public pillar: The essence of this pillar is that it fulfills the objective of redistributing to the old who are lifetime poor. It is managed by government, offers defined benefits that are not actuarially tied to contributions, financed out of (mostly) general tax revenue on a pay-as-you-go basis.

2. Mandatory savings pillar: The objective of this pillar is to facilitate individuals' efforts to save for their old age. It is a compulsory, preferably privately-managed, fully-funded defined-contribution program based on individual capitalization accounts. This pillar is not redistributive and thus minimizes labor market distortions and incentives to evade. It is likely to increase longterm savings more than the public pay-as-you-go pillar.

3. Occupational and Voluntary Pillars: The occupational pillar consists of privately managed pensions offered by employers as an incentive to attact and retain workers. The voluntary pillar includes other privately managed saving and insurance schemes that are often encouraged by tax incentives and are not redistributive.

To some extent these pillars are substitutes for each other, but they are not perfect substiutes because they have different goals and satisfy the needs of different groups. Sharing responsibility for old age security between two or more pillars achieves the multiple objectives of redistribution, saving and insurance at least cost, including evasionary and distortionary costs.

- This box draws on The Old Age Security Report, 1994. 


\section{The Present System and its Problems}

\section{A. Structure}

The Costa Rican pension system is very fragmented. There are 21 different schemes (regimes) with their own rules and conditions, covering approximately half of the working population. The main social security institution is the Caja Costarricense del Seguro Social - CCSS - that insures all covered private employees and about 60 percent of the public sector employees, which adds up to 45 percent of the working population (see Table 1). In addition, the CCSS administers a non-contributory welfare program for the government. The remaining 5 percent of the working population are covered by 19 special schemes which cover the rest ( 40 percent) of the public sector employees and are independent from the CCSS. Some of these, especially those for teachers, judicial, and financial employees, have traditionally been very generous. Special schemes are financed largely by the budget with public sector employees contributing only 10 percent of pension costs.

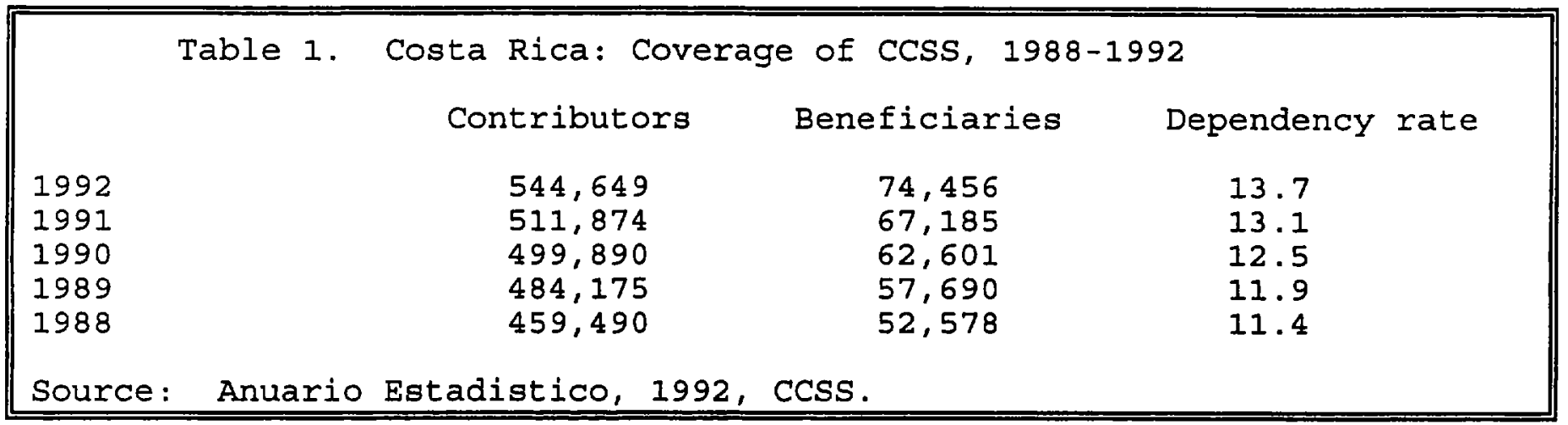

The fragmentation of the system and the differences in benefits and contributions impede labor mobility and cause inequalities among different groups. The government is in the process of unifying the special schemes. On June 15, 1992 a new General Framework Pension Regime Law was approved by the Legislative Assembly to bring the 17 special programs, except those for teachers and judicial employees, under common rules. ${ }^{2}$ The government also reformed the pension program for teachers, one of the most generous special programs, by capping the maximum contribution, tightening the eligibility criteria, and modifying the benefit formula. New employees started accumulating a capitalization fund. However changes in the retirement age and benefits were contested and the case is still at the constitutional court. Furthermore, the unification is not valid for existing pensioners and contributors, and therefore the transition from the fragmented system to a uniform one will take a long time. ${ }^{3}$

2 Originally the new law intended to bring all 19 regimes under one unified scheme but strong political opposition led to exclusion of the schemes for teachers and the judicial system.

3 Originally the Law intended to move everyone currently in the special regimes into the unified scheme but the Constitutional Body ruled that the move for the existing pensioners and contributors could only be voluntary. Given that the special regimes are much more generous than the unified scheme, the existing pensioners have no incentive to move to the new scheme. 
Table 2 provides a breakdown of CCSS revenue and expenditures. In 1994, the government plans to spend 32.5 billion colones on pensions ( 26 billion on special regimes, 6.5 to partially cover the contribution to CCSS) out of a 213 billion colones budget. The government has not been fully paying its contributions to CCSS. After the 1993 payment of 9 billion colones, the government still owes CCSS 13.8 billion colones in principal and 3.3 billion colones in interest.

\begin{tabular}{|c|c|c|c|c|c|}
\hline \multirow{3}{*}{ Costa Rica: } & \multicolumn{4}{|c|}{ Table 2} & \\
\hline & \multicolumn{2}{|c|}{ Distribution of } & \multicolumn{3}{|c|}{ CCSS Revenue and Expenditures } \\
\hline & 1988 & 1989 & 1990 & 1991 & 1992 \\
\hline \multicolumn{6}{|l|}{ Revenues (in $\%)$ : } \\
\hline workers & 22.45 & 22.94 & 22.79 & 21.56 & 22.68 \\
\hline employer & 41.49 & 42.48 & 40.83 & 37.57 & 42.73 \\
\hline state & 2.24 & 2.30 & 2.36 & 2.15 & 2.30 \\
\hline investment & 32.93 & 31.52 & 33.12 & 35.89 & 31.78 \\
\hline other & 0.90 & 0.77 & 0.90 & 0.70 & 0.52 \\
\hline \multicolumn{6}{|l|}{ Expenses (in $\frac{\circ}{b}$ ) } \\
\hline health & 9.65 & 9.54 & 9.63 & 9.59 & 9.63 \\
\hline pensions & 84.55 & 83.96 & 84.69 & 84.50 & 84.65 \\
\hline administrative & 4.61 & 5.08 & 4.19 & 4.77 & 4.84 \\
\hline other & 1.20 & 1.42 & 1.49 & 1.15 & 0.87 \\
\hline total/gdp & 1.73 & 1.81 & 1.93 & 1.93 & \\
\hline Source: Costa Rica & Indicac & $\mathbf{s}$ de $\mathrm{Se}$ & eguridad Sc & $11988-$ & \\
\hline
\end{tabular}

Table 3 shows government's spending on special pension programs. Although special programs cover only 5 percent of the working population, they absorb 80 percent of government spending on pensions. As a percent of GDP, government's spending on special regimes has also been increasing, reaching approximately 2 percent in 1992.

Total pension expenditures have been approximately 4 percent of GDP. Half of this amount is due to CCSS's expenditures and the rest is government spending on special programs. Approximately 10 percent of CCSS's expenditures go to health benefits provided to beneficiaries of the program. International experience shows that as populations age, health expenditures increase at a much higher rate, contributing to the financial problems of the pension systems. Health and pension programs should be separated to avoid this problem and to ensure a close link between contributions and benefits. 


\section{Table 3}

Costa Rica: Government Expenditure on Special Pension Programs (in million colones)

$\begin{array}{lcccr} & 1990 & 1991 & 1992 & 1993^{*} \\ \text { Teachers } & 6,023.5 & 8,008.3 & 11,849.6 & 9,051.7 \\ \text { Finance } & 1,973.9 & 2,524.0 & 3,123.1 & 2,646.8 \\ \text { Communications } & 70.7 & 76.6 & 620.1 & 528.1 \\ \text { Others } & 2,056.8 & 2,431.2 & 1,730.1 & 1,486.7 \\ \text { Total } & 10,124.9 & 13,040.1 & 17,322.9 & 13,713.3 \\ \text { \% of gdp } & 1.94 & 1.89 & 1.97 & \\ \text { * as of September 1993. } & & & & \\ & & & & \\ \text { Source: Costa Rica Ministry of Finance. }\end{array}$

\section{B. The Level of Benefits}

Benefits vary considerably across individual schemes depending on the definition of pensionable salary, required length of service, replacement rates, and retirement age. Special schemes tend to have more generous benefits and lower retirement ages than the CCSS scheme. In general, the level of benefits is very high and difficult to sustain in the long run. The following features of the CCSS scheme highlight the reasons for the high cost of the system.

(i) Retirement Age: The normal retirement age was recently increased to 59 years 11 months for women, and 61 years 11 months for men. Retirement from covered employment is not necessary to receive a pension. Many developing countries have low retirement ages due to the shorter life expectancy and poorer health of old people. In developed countries, however, where life expectancy is higher, retirement age is usually 65 or older. Given that Costa Rica has a life expectancy of 76 years there is still room to increase the retirement age. In principle normal retirement age should be extended in line with improvements in life expectancy and productive ability of older people, since low retirement ages with high life expectancy add considerably to the financial burden of pension systems.

(ii) Replacement Rate: The replacement rate has recently decreased to 60 percent of pensionable salary, plus .0835 percent for each month worked over 20 years. Thus, a worker with 40 years of service can expect a replacement rate of over 80 percent. Although still very high, this represents an improvement over the replacement rates of 80-100 percent before the 1993 reform. In special schemes the replacement 
rate is generally 100 percent. These replacement rates are extremely high and unsustainable in the long run and should be lowered considerably. In addition, to start with such a high base pension favors workers with short length of service. Instead of a high base pension, having a constant accrual rate for each year or making the pension proportional to actualized average lifetime earnings would avoid this distortion.

(iii) Vesting Requirements: For public and private employees, the required length of service for a normal pension is 20 years. Until recent changes took place, however, private sector employees could receive a minimum pension by just working 5 years. This led to distortions and adverse distributions in the system. It is also easier for the private sector workers to evade the system by either not contributing or under-reporting their income. In this way, the system redistributes from public to private sector employees. On the other hand, public sector workers who just miss the required minimum (by working only 19 years) do not qualify for any pension unless they continue to contribute. To avoid such injustices, public and private sector employees should be treated equally and proportional pensions should be paid instead of using minimum vesting requirements.

(iv) Minimum and Maximum pension: Minimum and maximum pensions are commonly used as redistributive devices. CCSS has both a minimum and a maximum pension. Minimum pensions are common not only for redistributive purposes but also as means of protecting pensioners against inflation. They are generally set as a percentage of minimum wage. Costa Rica's is 80 percent of the minimum wage, which is 17,600 colones. The maximum pension is used to prevent high replacement rates for individuals with high earnings and is another way of de-linking the contributions and benefits. For Costa Rica it is 120,000 colones at the normal retirement age, and 175,000 colones if retirement is postponed. However, when the maximum pension is specified as a level it causes evasion since workers try to underreport their incomes and contribute less, to just qualify for the maximum pension. This is especially true since there is no ceiling on taxable wages. Setting the benefit ceiling as a percentage of a person's pensionable salary but decreasing replacement rates with salary would be a better way of capping the pensions, but retaining a link between the earnings and pension benefits.

(v) Pensionable Salary: Pensionable salary is based on the highest 48 monthly wage or salary payments during the last 5 years of coverage. In the private sector, this system encourages under-reporting of salaries during most of a person's career. In the final years, salaries are reported high enough to qualify for the maximum pension. Use of a longer term or even average lifetime actualized earnings would avoid these distortions. Use of actualized lifetime earnings would also make accrual rates unnecessary.

(vi) Inflation Indexation: Inflation indexation is very inadequate and ad hoc, and causes capricious redistributions. It is common practice among developing countries to promise high replacement rates, and to ease the resulting financial burden by not adequately indexing benefits to inflation. Costa Rica is not an exception. First, calculation of the pensionable salary on which the initial pension is based ignores inflation completely. Since the pensionable salary can cover a five year time period, this can mean considerable inflation (annual inflation has been approximately 15 percent over the last years). Pensioners of special schemes avoid this erosion of the pensionable salary to a large extent, since their pensions are based on the last year's salary. Second, after retirement, pensions are adjusted at irregular intervals, based on "availability of financing." This leads to a significant erosion in the standard of living of retirees as they age, until they reach the minimum pension. 
In principle, the adjustments are based on prices or wages, whichever is lower. If adjustments were made regularly, this practice would minimize the burden on the fund, and is advisable. Although price indexation protects the standard of living of pensioners, it may cause a big financial burden on the system if the real wages are falling. Wage indexation would avoid this problem, but would require higher contribution rates than price indexation if real wages are rising. Using price or wage indexation, whichever is lower, avoids these problems. However, whatever the method of indexation, inflation should be taken into account regularly in calculating the pensionable salary and in adjusting the pensions.

(vii) Survivor and Disability Pensions: Survivor pensions vary from 40 to 70 percent of the pension benefits depending on the age of the survivor, and whether he/she is the spouse or child. They require 2 years of contributions by the insured. Disability pensions are equal to old age pension (which is 60 percent of the pensionable salary unless the person has worked over 20 years) and require only 3 years of service. Before the 1993 reforms, disability pension could be over 80 percent of the pensionable salary with just 3 years of service. Due to the generous terms of the disability pension, individuals substituted it for early retirement, which does not exist in Costa Rica. As a result, 30 percent of the expenditures of the pension system goes to disability payments. To prevent abuse of the system, the disability rate should be further lowered and its eligibility requirements should be tightened.

\section{The Level of Contributions}

Despite the generous replacement rates Costa Rican contribution rates are quite low by international standards. CCSS's contibution rate is a total of 7.5 percent, split between employees ( 2.5 percent), employers ( 4.75 percent), and the government ( 0.25 percent). ${ }^{4}$ In the past, the government failed to make its contributions to the fund regularly. The special schemes also require very low contribution rates compared to the replacement rates they promise. The recent increase in the contribution rate of the Teacher's Scheme from 7 to 9 percent was contested in courts as unconstitutional. In special regimes workers' contributions cover approximately 10 percent of total expenditures. The rest are paid by the government.

Despite its relatively low contribution rate, CCSS suffers from extensive evasion by private sector employees. Workers try to evade the system until later in their work life, when they start contributing to become eligible for a pension. Even then, under-reporting of salaries is common by high income workers, and only the amount that entitles them to maximum pension is reported. For low income workers, there is an incentive to inflate the level of reported salaries during the last five years of employment that form the basis for calculating the pensionable salary. The weak link between the contributions and benefits leads the contributers to view the system as a tax on labor rather than as a forced savings scheme.

4 Although pension contribution rates for workers is low, workers are already subject to very high tax rates, which may hamper the feasibility of reforms that include increases in contribution rates. 


\section{Financial Condition of the Present System}

\section{A. Financial Equilibrium}

In a pure pay-as-you-go system, the revenues of the pension plan must equal its expenditures. Most real world public pension schemes are not pure pay-as-you-go and accumulate a surplus in their early years and incur a deficit later on. However, the aim of most public pillars is to balance revenues and expenditures over the long run. In a pay-as-you-go system financed by a payroll tax, the following equation holds:

$$
\mathrm{C}=\mathrm{R} * \mathrm{D}
$$

where,

$\mathrm{C}$ is the contribution rate as a percentage of average wages, $\mathrm{R}$ is the replacement rate, which is given by the average pension as a percentage of average earnings at retirement, and $\mathrm{D}$ is the dependency rate, which is given by the number of beneficiaries as a percent of the number of contributors.

The contribution rate required to cover the cost of a pay-as-you-go system depends on two major variables, the dependency rate and the benefit rate. For example, if there is one retiree for every ten workers and if beneficiaries have been promised an average pension that equals 80 percent of the average wage, then an 8 percent contribution rate is needed for the system to cover its costs. But if the population ages so that there is one retiree for every five workers, then the contribution rate has to go up to 16 percent to keep its promise of 80 percent replacement rate. Conversely, to keep the contribution rate at 8 percent, the replacement rate has to be reduced to 40 percent.

Both the dependency rate and replacement rate depend on several demographic and economic factors. The dependency rate is affected by factors such as labor force participation, unemployment, evasion, retirement age, early retirement, number of survivors and disabled workers, changes in birth and mortality rates, and system maturation. Similarly the replacement rate is affected by the definition of pensionable salary, by minimum and maximum pensions, by inflation indexation, and by the adjustments made for early retirement and disability and survivors' pensions.

In a partially funded scale premium system, the required contribution rate is initially increased by the targeted increase in reserves, but later on with the accumulation of reserves, it is reduced by the amount of investment income available in excess of administrative expenses. The impact of the investment income depends on the size of the reserves and how well they are invested.

\section{B. Current Financial Position}

In Costa Rica, the CCSS generated a surplus throughout 1975-85 (except in 1981) but the sicknessmaternity program had a deficit during 1975-81 and was subsidized by the pension program. In 1981, a law prohibited this type of cross-subsidy, and by 1986 reserves were no longer invested in the sicknessmaternity program. More recently, the system has been under increasing pressure due to generous benefits, low contribution rates, poor investment performance, and evasion through not contributing or under-reporting. The government has not been able to pay its contributions to CCSS. The government is 
also under pressure from specialized schemes which have very low contribution rates and early retirement ages for the replacement rates they offer.

In 1988, an actuarial review concluded that costs of the system would exceed its revenues by 1993. It recommended a rise in the contribution rate, or a rise in the retirement age, or a mixture of both to prevent a crisis. The recent reforms undertaken by the government aimed to: (i) decrease the financial pressures on CCSS by increasing the retirement age and by modifying the benefit formula to decrease the replacement rate; (ii) unify all special schemes under one scheme; and (iii) create a system of complementary private pensions.

Efforts to unify special programs are still under way. Voluntary savings schemes are emerging although they are very limited. Legislation to regulate these private savings plans is pending approval. The increase in the retirement age and the modification of the benefit formula, however, were not adequate measures to reduce the financial pressures on CCSS. The most recent actuarial review (1993) showed that even with these changes, the system will not be able to maintain equilibrium and will run into trouble by 1996. This indicates the urgency of further reforms in the system.

\section{Long Run Prospects}

The longer run prospects for financial viability are dominated by demographic conditions. Table 4 shows the sharp increase in the elderly population (60 and above) expected in the coming decades. By the year 2020 , the elderly population will have more than doubled from its current level, and by 2050 , it will have quadrupled as a percentage of the total population.

\begin{tabular}{|c|c|c|c|c|}
\hline \multicolumn{5}{|l|}{ Table 4} \\
\hline \multicolumn{5}{|c|}{ Costa Rica: Demographic Structure, 1990-2050 } \\
\hline & 1990 & 2000 & 2020 & 2050 \\
\hline Percent of Population Age 60 and Above & 6.4 & 7.8 & 14.3 & 26.4 \\
\hline Percent of Population Age 65 and Above & 4.2 & 5.4 & 9.5 & 20.1 \\
\hline $\begin{array}{c}\text { Dependency Rate: } \begin{array}{c}\text { ratio of population aged } 60 \text { and above to } \\
\text { population aged } 20-59\end{array} \\
\text { Also number of retirees supported by each worker }\end{array}$ & .133 & .152 & .256 & .555 \\
\hline 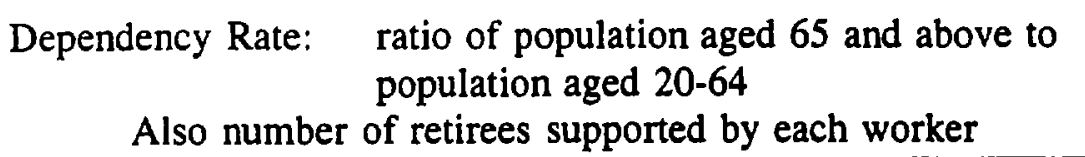 & .084 & .100 & .156 & .37 \\
\hline
\end{tabular}


Based on the current contribution rate and current replacement rate, the simulation model described in the Annex is used to compute the number of workers required to support each retiree. One method of assessing the prospects for financial viability is to compare the required worker per retiree ratio with the number of potential workers per potential retiree in the future based on demographic projections. If the average worker enters the labor force at age 18 and retires at age 61 , under the current system, this worker would receive 83 percent of the average of the four highest years' salary. With the current contribution rate of 7.5 percent, if fully indexed, such a pension system, would require 13.4 workers per retiree. Even as far back as 1985 , this large a workforce relative to retiree population did not exist.

The current surplus in the CCSS exists due to incomplete inflation indexation. Inflation increases the nominal value of the contributions coming into CCSS, but if the benefits are not increased to match inflation, then the contributions will exceed expenditures. Table 5 shows the average pension as a percentage of average wage for the years 1985-91, suggesting that actual pensions paid are far below what has been promised. The numbers are even worse than they appear in that the denominator in Table 5 is the average wage, not the average of the four highest years' salary. For example, the average pension of the elderly between 1985 and 1991, as shown in Table 5, was 68.5 percent of the average wage, but only about 40 percent of the average individual's final 4 year salary. With the old age pension set at the 1985-91 average of 68.5 percent of the average wage, the required worker to retiree ratio to maintain financial solvency falls to 8.7 .

\begin{tabular}{|c|c|c|c|c|c|c|c|}
\hline \multicolumn{8}{|c|}{ TABLE 5} \\
\hline \multicolumn{8}{|c|}{ Costa Rica: Effective Replacement Rates, 1985-91 } \\
\hline & 1985 & 1986 & 1987 & 1988 & 1989 & 1990 & 1991 \\
\hline $\begin{array}{l}\text { Ratio of Average Pension (All) to } \\
\text { Average Wage }\end{array}$ & 51.9 & 42.3 & 48.2 & 42.6 & 37.5 & 38.9 & 41.7 \\
\hline $\begin{array}{l}\text { Ratio of Average Pension (Old Age) to } \\
\text { Average Wage }\end{array}$ & 85.5 & 72.4 & 78.8 & 64.5 & 56.2 & 59.1 & 63.1 \\
\hline
\end{tabular}

Figure 1 shows the potential worker per potential retiree ratio from 1985 to 2075 based on World Bank population projections. All individuals aged 18 to 61 are considered to be potential workers, all individuals aged above 61 are considered potential retirees. The bars show the ratio of potential workers to potential retirees at five year intervals. It is clear that the pension promise, which requires 13.4 workers per retiree, sannot be fulfilled even today. At some point between 1990 and 1995, even the current inflation-reduced benefit, which requires 8.7 workers per retiree, will run into deficit. Evidence from the CCSS comes to the same conclusion. The 1992 CCSS Statistical Yearbook shows that the contributions received total 17 billion colones, while expenditures amounted to 16.7 billion colones, suggesting that even a small rise in the elderly population will cause expenditure to exceed contributions. 


\section{Potential Workers Per Retiree in Costa Rica}

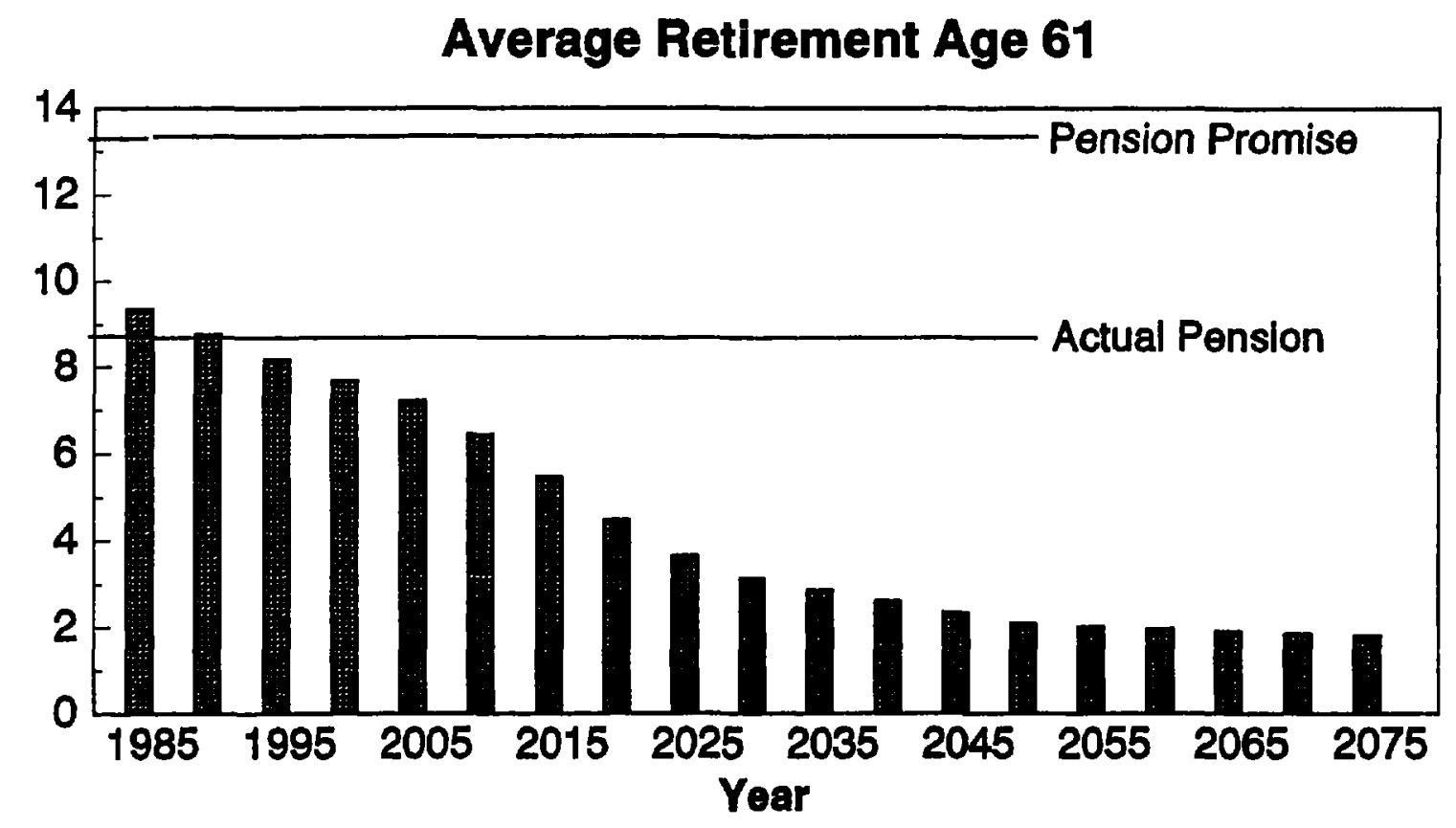

Figure 1

Although the analysis in Figure 1 shows potential worker to potential retirees, the actual worker to retiree ratio may deviate somewhat. A rise in real wage growth from the current level of growth will lower the required worker to retiree threshold, allowing the system to remain solvent slightly longer. Similarly, expansion of pension coverage to include previously uncovered workers will temporarily enlarge the worker-retiree columns for about 40 years, again extending the period of solvency. On the other hand, evasion will shrink the worker-retiree columns, increasing the likelihood of insolvency. In fact, the contributor/beneficiary ratio in 1992 was 7.3, below that shown in Figure 1. Part of the explanation lies in the large number of invalidity pensions which result in both a reduction in the contributors and a rise in the beneficiaries. Financially, this has been balanced by the lower average pensions received by these individuals, as shown in Table 5. But what is clear from Figure 1 is that while labor market conditions may speed up or delay the precise date of financial insolvency, the current system cannot be sustained in the long run. 
The surplus built by the current system, roughly 56 billion colones, can also be used to delay financial collapse. The fund is roughly equal to 3.4 years worth of current benefits. Since contributions will continue to pay for the bulk of benefits for the next 10 years, the fund will not be fully exhausted until around 2010. The system will be completely bankrupt at that point. Since transition to a more sustainable pension system will involve some costs, our proposal is to undertake reform while this surplus exists so that the surplus can be used to alleviate transition costs.

Another way to evaluate the financial sustainability is to calculate the contribution rates required to sustain the actual current benefit level of 68.5 percent of average wage. Table 6 shows a sharp rise in contribution rates, particularly after 2015 . The government is clearly unable to make up the difference between the current employer-employee contribution of 7.25 percent and the required contribution rate in the long run. And this analysis excludes government costs arising from special schemes. The government is currently spending approximately 2 percent of GDP on special schemes. If we assume the increase in costs for special schemes is similar to that for the CCSS, then special schemes would cost about 5 percent of GDP by 2025 and the CCSS cost would be about 10 percent of total wages by 2025 , or approximately another 2.8 percent of GDP. If government expenditures remain at their current level of 23 percent of GDP, pension payments would absorb more than a third of the budget. by 2025 (as opposed to 15 percent in 1994).

A final method of looking at the financial sustainability of the CCSS is to look at the average replacement rates which would be viable keeping the current contribution rate fixed. In the past, the pension benefit has simply been inflated away, reducing the average replacement rate. If this practice were to continue, by 2025, the benefit would be about 41 percent of the 1995 benefit. Table 6 shows the future replacement rates resulting from a fixed 7.5 percent contribution. The current retirees would clearly have

\begin{tabular}{|l|c|c|c|c|c|c||}
\hline \multicolumn{10}{|c|}{ Table 6 } \\
\hline \multicolumn{10}{|c|}{\begin{tabular}{c} 
Costa Rica \\
Required Contribution Rates and Viable Replacement Rates \\
Under Changing Demographic Conditions \\
\hline
\end{tabular} 11995} & 2005 & 2015 & 2025 & 2050 & 2075 \\
\hline $\begin{array}{l}\text { Contribution Rates Required to Provide a } \\
\text { Pension Worth 68.5\% of Average Wage }\end{array}$ & 8.0 & 9.0 & 11.9 & 17.8 & 31.2 & 36.1 \\
\hline $\begin{array}{l}\text { Pension as a Percentage of Average Wage } \\
\text { Resulting from a 7.5\% Contribution }\end{array}$ & 64.6 & 57.0 & 43.2 & 28.8 & 16.4 & 14.2 \\
\hline
\end{tabular}

benefitted at the expense of their children and grandchildren since the 14.2 percent of average wage available to retirees in 2075 (less than 30 percent of minimum wage) is not enough to provide a living standard above the poverty line.

D. Investment Performance 
Poor investment performance of the Costa Rican pension fund worsens its financial problems. The real returns on CCSS pension investments have been either negative or low in the past, leading to a shrinkage in the fund in real terms. The composition of CCSS investments are given in Table 7.

The largest component of the investment portfolio is in short term investments which are approximately 95 percent government paper and 5 percent bank deposits. The next largest component is long term investments which are again almost completely held as government bonds, which typically yield negative real returns. Mortgages are mostly to CCSS employees at below market rates, and therefore also have low yields, and very high administrative costs. Finally, government arrears to CCSS have also been depleting the reserves. This is a very poor investment record, especially since real interest rates are very high in Costa Rica, at 15 percent.

It is necessary to enhance the investment performance of pension funds. The pension fund should be encouraged to invest in safe marketable securities in addition to government bonds. It is difficult for a small country like Costa Rica to invest only domestically and diversify risks and earn high rates of return. In time, as their expertise develops pension funds should be allowed to invest internationally as well as domestically, perhaps up to 50 percent of their reserves.

CCSS and the Ministry of Finance are in the process of designing a new investment strategy for CCSS which will require the government to pay positive real rates of return on its bonds and which will allow CCSS to invest in the stock market.

Table 7

Costa Rica: Real Return on and Compostion of CCSS Investments

\begin{tabular}{||l|l|l|l|l|l|l|l|l|l|l|l||}
\hline \multirow{2}{*}{ Year } & \multicolumn{2}{l|}{$\begin{array}{l}\text { Short Term } \\
\text { Invest. }\end{array}$} & \multicolumn{2}{l|}{$\begin{array}{l}\text { Long Term } \\
\text { Invest. }\end{array}$} & \multicolumn{2}{l|}{ Mortgages } & \multicolumn{2}{l|}{$\begin{array}{l}\text { State } \\
\text { Arrears }\end{array}$} & \multicolumn{2}{l|}{$\begin{array}{l}\text { Other } \\
\text { real } \\
\text { ret. }\end{array}$} \\
\cline { 2 - 10 } & $\%$ & $\begin{array}{l}\text { real } \\
\text { ret. }\end{array}$ & $\%$ & $\begin{array}{l}\text { real } \\
\text { ret. }\end{array}$ & $\%$ & $\begin{array}{l}\text { real } \\
\text { ret. }\end{array}$ & $\%$ & $\begin{array}{l}\text { real } \\
\text { ret. }\end{array}$ & $\%$ & $\begin{array}{l}\text { real } \\
\text { ret. }\end{array}$ & \\
1987 & 43 & 7 & 27 & -3.6 & 15 & 1.4 & 3 & -8.4 & 12 & -12 & .04 \\
1988 & 35 & -2.2 & 31 & -7.3 & 18 & -4.7 & 4 & -15.1 & 12 & -17.5 & -6.0 \\
1990 & 40 & 12.2 & 18 & -3.4 & 22 & 9.6 & 3 & -5.01 & 17 & -6.4 & 6.7 \\
1991 & 58 & -2.6 & 14 & -9.0 & 26 & -2.4 & 4 & -16.4 & 16 & -19.1 & -6.85 \\
\hline
\end{tabular}

Source: Inversiones De La Reserva Del Seguro de Invalidez, Vejez y Muerte, Departamento Actuarial, 1992. 


\section{Options for Reform}

\section{A. Objectives of Reform}

Ideally pension systems should facilitate individuals' efforts to save for their old age and redistribute additional income to the old who are lifetime poor. The Costa Rican public pension system is costly and unsustainable in the long run. Furthermore, although the system intends to enhance income equality and provide old age security, its structure leads to the following perverse redistributions:

* The system is supposed to redistribute toward the poor, however the government contributes to CCSS and even more to the special regimes with funds raised from general tax revenue. Therefore, the system redistributes from uncovered (poor) to the covered, and among the covered employees from people covered by CCSS to those covered by special regimes.

* The system also redistributes from longer service employees to shorter service employees since it has a declining accrual rate. In the benefit formula the first 20 years is worth 60 percent replacement rate whereas the next 20 years brings approximately 20 percent more. There is no added benefit after the age of 65 .

* The system greatly redistributes to disability pensioners due to lax regulations in eligibility and generous benefits.

* The minimum eligibility requirement is another source of adverse redistibution since individuals who do not complete their 20 years are not eligible for any pension.

* The system is supposed to protect the old against inflation but inadequate indexation is used to lower the effective replacement rates. The pensions erode down to the minimum pension as people age.

* The weak link between contributions and benefits leads to under-reporting of salaries and evasion. Thus, the system redistributes from those who can evade (private sector employees) to those who cannot (public sector employees).

* Like other defined benefit pension systems, the system redistributes from poor to high income people due to differences in life expectancy and differences in career patterns of earnings.

Some of these adverse redistributions are caused by design errors. However, not all of the Costa Rican pension problems are incidental design errors. Instead, they are basic to the public social security systems. Publicly managed old age security systems are inherently in conflict because they are asked to fulfill multiple goals that are not compatible, and this opens the door to strategic and political manipulation. In most cases they are supposed to provide social insurance in which contributions are related to expected benefits, and also to redistribute income toward the old who have been poor over their lifetime. In a redistributive system, such as the Costa Rican system, benefits are not closely linked to contributions. If 
the system is actuarially fair along insurance principles, the redistributive objective is not met. The combination of these two goals in one earnings-related scheme opens the door to worst of both worlds: nontransparent benefits are not linked to contributions, which privileged groups can manipulate to gain perverse redistributions. Many individuals regard their contributions as a tax, with all its distortionary consequences, especially the incentive to evade. This outcome is not inevitable but certainly wide-spread. See Box 2 for a brief review of recent international experience in the area of pension reform. 
Box 2 : International Experience in Pension Reform

The old age security problem exists all around the world, but it takes different forms. In most of Africa and parts of Asia the proportion of people who are old is relatively small and they have long been cared for by extended family arrangements, mutual aid societies, and other informal mechanisms. But as extended family ties weaken due to urbanization, mobility, wars and famine, these countries are being forced to reevaluate their reliance on informal systems. The informal system is coming under particular strain in countries where the proportion of the population that is old is growing rapidly due to medical improvements and declining fertility, as in East Asia. As a result of all these factors, several Asian and African countries are considering fundamental changes in the way they provide old age security. The challenge they face is how to move toward formal systems of income maintenance without accelerating the decline in informal systems, and how to avoid shifting a larger responsibility to government than it can effectively handle.

The need to reevaluate policy is even more pressing in Latin America and the transitional socialist economies that, in the past, introduced formal programs of old age security whose costs they can no longer afford. Early retirement, evasion and overlygenerous entitlements lead to a high ratio of beneficiaries to contributors and require payroll taxes of over 30 percent in many of these countries; this distorts the labor market and encourages further evasion. Not surprisingly these countries have been unable to pay the promised benefits and have reduced their real value, usually by failing to index pensions in the presence of high inflation.

Argentina tried to deal with the fiscal crisis and inflation of the late 1970's by raising contribution rates and indexing pensions. However, the indexation raised costs and increased contribution rates caused greater evasion. Combined with the unemployment of the mid-1980's, the result was a larger deficit. To avoid insolvency, Argentina arbitrarily reduced pension benefits below legally determined targets and increased general revenue finance. However, this arbitrary reduction of pension benefits was successfully challenged in courts and the government had to face unpaid pension liabilities, as well as a pension system that was in need of immediate reform. With the recent reforms, Argentina created a new public pension system and a new parallel private pension system. The new public scheme will be run on a funded basis and was created for new entrants into the labor force. The existing public scheme will not accept new members and will be phased out. There will also be a flat public pension for individuals who have contributed for at least 20 years.

Uruguay is in a similar condition. When the pension system ran into financial problems in the 1970's, authorities first responded by reducing real benefits through inadequate inflation indexation. However, legislation was passed to prevent this real decline, thereby necessitating increased contributions as well as government transfers. By 1989 contribution rates reached 30 percent of payroll, leading to substantial evasion. In 1990, 27 percent of total pension expenditures were covered by public treasury; this constituted 2.6 percent of GDP and about 10 percent of the government's general budget. Today, reforms are still being considered.

Although the Chilean pension system faced similar problems in the 1970's, Chile chose to undertake a fundamental reform of its pension system. It instituted a government-regulated but privately-run mandatory savings system supplemented by a pay-as-you-go public plan that guarantees a minimum benefit to workers with low incomes or interrupted employment careers who are not able save enough for adequate pensions. During its first ten years of operation, the new Chilean system accumulated resources equal to 30 percent of GDP and achieved an average real return of 13 percent per year, despite its relatively high operating costs. The success of Chile has encouraged other Latin American countries to consider a reform away from pay-as-yougo defined benefit systems toward fully funded defined contribution accounts.

Eastern European countries also suffer from strong financial pressures on their pension systems. These countries have widespread coverage, old populations, high expendirures relative to GDP, high payroll taxes that induce evasion and deter private sector growth, and promise early retirement with generous replacement rates. Unable to cope with the large macroeconomic shocks they have been experiencing, the transitional socialist countries cannot keep their pension promises and are reevaluating their old systems. A major deterrent to change is the large unfunded pension debt they owe retirees and older workers.

In several Asian and African countries, the pension system is based on national provident funds. These are forced savings schemes that involve the use of individual capitalization accounts operated by a public agency. In Singapore and Malaysia, where the level of contribution rates is very high, the provident funds have accumulated very large long-term resources, amounting respectively to 72 and 41 percents of GDP in 1987. The main difference with the Chilean scheme is the public management of funds. This has resulted in lower operating costs but also lower investment returns. In fact except for Singapore and Malaysia, provident funds in several Asian and African countries suffered from negative real rates of return.

Many countries in the Arab world as well as in Asia and the Middle East, such as Jordan, Turkey and the Phillippines, operate with partially funded scaled premium schemes. In general, these schemes face uncertain actuarial futures because of their growing maturity and the progressive aging of their covered populations. Most schemes also suffer from poor investment returns 
Box 2 : Continued.

on their accumulated reserves. The case of Egypt is particularly interesting. A very ligh contribution rate of 26 percent in relation to the very young demographic structure of the country has contributed to the accumulation of very large financial resources which amounted to 40 percent of GDP in 1988 . However, the reserves have been placed with the National Investment Bank to finance public expenditures and public sector companies. Negative real rates of return reduced the relative importance of pension reserves to 30 percent of GDP by 1991. The very high contribution rate in Egypt is not based on an actuarial assessment of future pension liabilities; instead the system is more of a tax on labor, used to fund the deficit of the public sector.

O.E.C.D. countries have paid substantial pensions during the last three decades, a period of prosperity during which poverty among the old declined faster than poverty among the young. But they too face problems with their old age security systems, as their population ages and productivity stagnates. This has led to inter-generational conflict between the old retirees who are getting public pensions and the young workers who are paying high taxes to finance them. Required payroll tax rates are expected to rise by several percentage points and benefits to fall, over the next two decades, so the young workers may never recoup their contributions. Lurking in the background is the suspicion that past social security arrangements may have discouraged work, saving and productive capital formation and thereby contributed to the current fiscal deficit and economic stagnation, that these arrangements might not have been adopted in their present form if their full effects had been foretold and if young as well as old generations had participated in the decision. Many O.E.C.D. countries appear to be moving toward the growth of privately managed personal or occupational pension plans for higher income groups, combined with publicly managed pension plans targeted toward basic needs and lower income groups. In addition, almost all have raised retirement ages and/or contribution rates in addition to reducing benefits.

This brief tour around the world shows that there are strong pressures on the financial viability of public pension systems that operate on a pay-as-you-go or partially funded basis. There is an international trend towards a lowering of pension benefits offered by public schemes and toward the adoption of a multi-pillar structure with privately-run systems complementing the benefits offered by the existing public schemes. The promotion of private pension schemes increases the importance of regulation and supervision in order to ensure the safety and profitable investment of accumulated funds. However, they appear to enjoy various advantages over unfunded or partially funded public schemes and their role is growing in many developed and developing countries.

This review draws extensively on The Old Age Security Report, 1994 and Vittas and Skully, 1991.

\section{B. Impact of the Public Pension System on the Broader Economy}

Countries evaluating their pension systems and considering different reform options should be aware of the impact a public pension system has on the broader economy. In fact, public pension systems have important effects on labor markets, saving and capital markets, income distribution and poverty alleviation, and public finance.

(i) labor markets: The payroll tax financed public pension systems have three important effects on labor markets. First, the payroll tax which is not linked closely to benefits may lead workers to withdraw from the labor force. Second, it will make it more likely for workers to escape to the informal sector. In countries where only a minority of the total labor force is covered and the informal sector is large, evasion is particularly easy. Third, the benefit formula may encourage earlier retirement, since absence of rewards or the presence of penalties for late retirement are common. All of these effects lead to lowering of the supply of trained workers and therefore lower labor productivity.

(ii) savings and capital markets: The savings impact of a pay-as-you-go versus funded pension system is not clear in pension literature. Still, a funded plan has the potential for a more positive effect on 
long term savings, capital accumulation, financial market development and economic growth than a pay-asyou-go plan. However, whether this potential is realized depends on how the funds are managed and how they interact with the government's spending patterns. To ensure efficient allocation of these reserves, governments should compete for their use with other domestic and international borrowers. The beneficial effects of funded plans are lost if they are run by monopolistic public managers.

(iii) income distribution and poverty alleviation: Even if there are no design problems, in public pension schemes little redistribution takes place from rich to poor over their lifetime. The basic reason is that upper income contributors enter the labor force later in life and live longer after retirement, thereby contributing less and receiving more lifetime benefits than lower income contributors. A second type of transfer which takes place in all unfunded or partially-funded schemes is the intergenerational transfer. Generally, earlier older generations tend to do better than later generations regardless of income level since the systems mature and contribution rates have to be increased in time. In some cases, redistributions have gone from low income young generations to high income older generations.

(iv) public finance: Although pension reserves are usually kept nominally separate from government funds, the administrators are under the authority of government and the funds are almost invariably required to be invested in government securities or in securities of state enterprises. International money managers and international diversification of the portfolio would improve matters, but this is not usually allowed. The resulting negative real rates of return mean that money disappears in real terms; instead of being accumulated to pay future pensions, capital is misallocated in very capital-scarce countries. In effect the payroll tax is being used in place of other taxes to finance general governmental expenditures.

The following sections discuss two reform options. The first is a limited reform option, which keeps the present sytem and outlines the changes that are needed to make the system financially sustainable and more equitable. The second is a more radical reform that would go beyond changing the basic parameters of the existing system and recognizes the conflicting goals of the present system. This reform would lead to a multi-pillar old age security system (see Box 1).

\section{C. $\quad$ Limited Reform}

The following is a list of reforms that retains the present system but makes it financially sustainable and more equitable by eliminating some design flaws. However, it should be noted at the outset that financial sustainability in the long term will require either enormously high contribution rates, or less than poverty level benefits, neither of which may be feasible or desirable. So while the limited reform may be attractive today and will remove some of the inequities in the existing system, in the longer term a more radical reform will be required.

To make the system more equitable and to enable redistributions from high income to poor individuals, the following unintended redistibutions should be removed: 
* To avoid redistributions among different schemes and minimize redistributions from poor to rich: The government has started the unification process for the specialized schemes. Ideally, all schemes, including CCSS, should be unified under one scheme for obvious equity reasons. The government is currently considering extending the coverage of CCSS to all the active population or even making it universal. To the extent that covered workers are in higher income groups than uncovered workers, care must be taken not to finance benefits for the former out of taxes paid by the latter. As coverage expands, lower income groups who enter later may have to pay higher contributions and get a lower rate of return than the first groups to be covered under a pay-as-you-go plan. It is very important to have a benefit structure that counters this regressivity stemming from inter-generational transfers as coverage expands. All defined benefit pension systems redistribute from poor to high income people to some extent. These are inevitable and arise from differences in life expectancy between low and high income people and from differences in career patterns of earnings.

* To avoid redistributions from public sector employees to those in the private sector, both covered under CCSS: All covered workers under CCSS, public and private employees alike, should be treated equally. At present private sector employees can evade the system by under-reporting their salaries for most of their careers and get high pensions by inflating or correctly reporting their salaries for the last five years. A stronger link between benefits and contributions would eliminate most of the incentives to evade. Changing the pension base from salaries in the last five years to average lifetime earnings corrected for inflation would eliminate some of the incentives for evasion.

* To avoid redistributions toward disability pensioners: In Costa Rica until 1991 more people were receiving disability pensions than old age pensions. Now the numbers are roughly equal. The recent change in the benefit formula is not adequate to counter this effect. Disability pensions should be less than old age pensions and requirements to qualify for this pension should be more strict. Furthemore, without an explicit early retirement provision, individuals tend to use disability pensions for early retirement. Including an explicit early retirement provision with appropriate actuarial reduction in pension benefits to compensate for the increased duration of those benefits would eliminate some of the problems with the disability pensions.

* To avoid redistributions from long-service to short-service workers: In the benefit formula the first 20 years are valued three times higher than the next 20 years. Furthermore, delaying retirement after age 65 is not rewarded. Using a constant accrual rate would prevent this redistribution. Alternatively, use of actualized lifetime or long-term earnings would obviate the need for using annual accrual factors.

* To avoid redistributions from those who cannot complete their minimum eligibility period to those who do: CCSS's minimum eligibility requirement of 20 years discriminates against workers with less than the minimum vesting period who lose their right to any pension. Providing proportional pensions based on the number of years contributed would remove this redistribution.

* To avoid redistributions due to inadequate indexation for inflation: This requires two changes. First the calculation of the pensionable salary should adjust the last five years salaries for inflation. This would avoid redistributions from people who retire during high inflationary periods to those who retire during low inflationary periods (since they retire with a higher real pension). Second, pensions after 
retirement should be indexed for inflation regularly. If targeted replacement rates are too high they should be lowered explicitly. Reducing replacement rates implicitly through inadequate indexation affects the real pensions of older beneficiaries and hurts people with longer longevity.

To make the system financially sustainable in the medium term, the following changes can be made:

* Increase the normal retirement age: To contain the increase in costs and lower the dependency rate, the normal retirement age could be gradually increased to 65 , or even 67 years. Figure 2 shows the effect of raising the retirement age to 65 from the current average of 61 . The system can remain financially solvent, but only until somewhere between 2010-2015.

\section{Potential Workers per Retiree in Costa Rica}

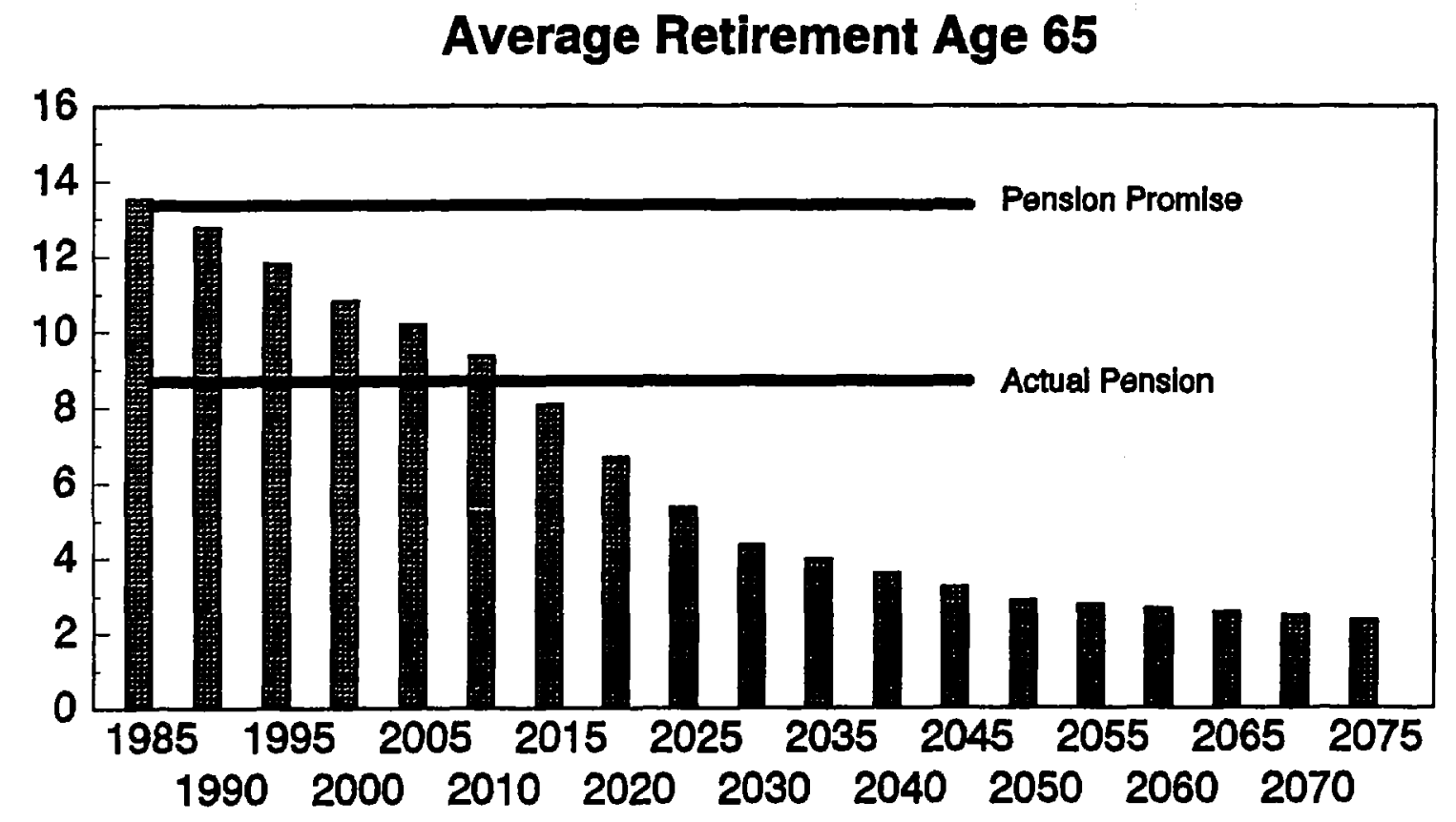

Figure 2

* Provide actuarial increments for retirement after 65: This would remove existing distortions in 
favor of earlier retirement.

* Increase the contribution rate and eliminate contributions from the government: To avoid financial problems in the near future, contribution rates should be gradually increased to over 10 percent. Government contribution should be eliminated since this redistributes from uncovered to covered workers. Figure 3 shows the impact of increasing the contribution rate to 10 percent while keeping the retirement age at 61 . Again, this reform prolongs financial viability for a number of years until somewhere between 2010 and 2015.

\section{Potential Workers Per Retiree in Costa Rica}

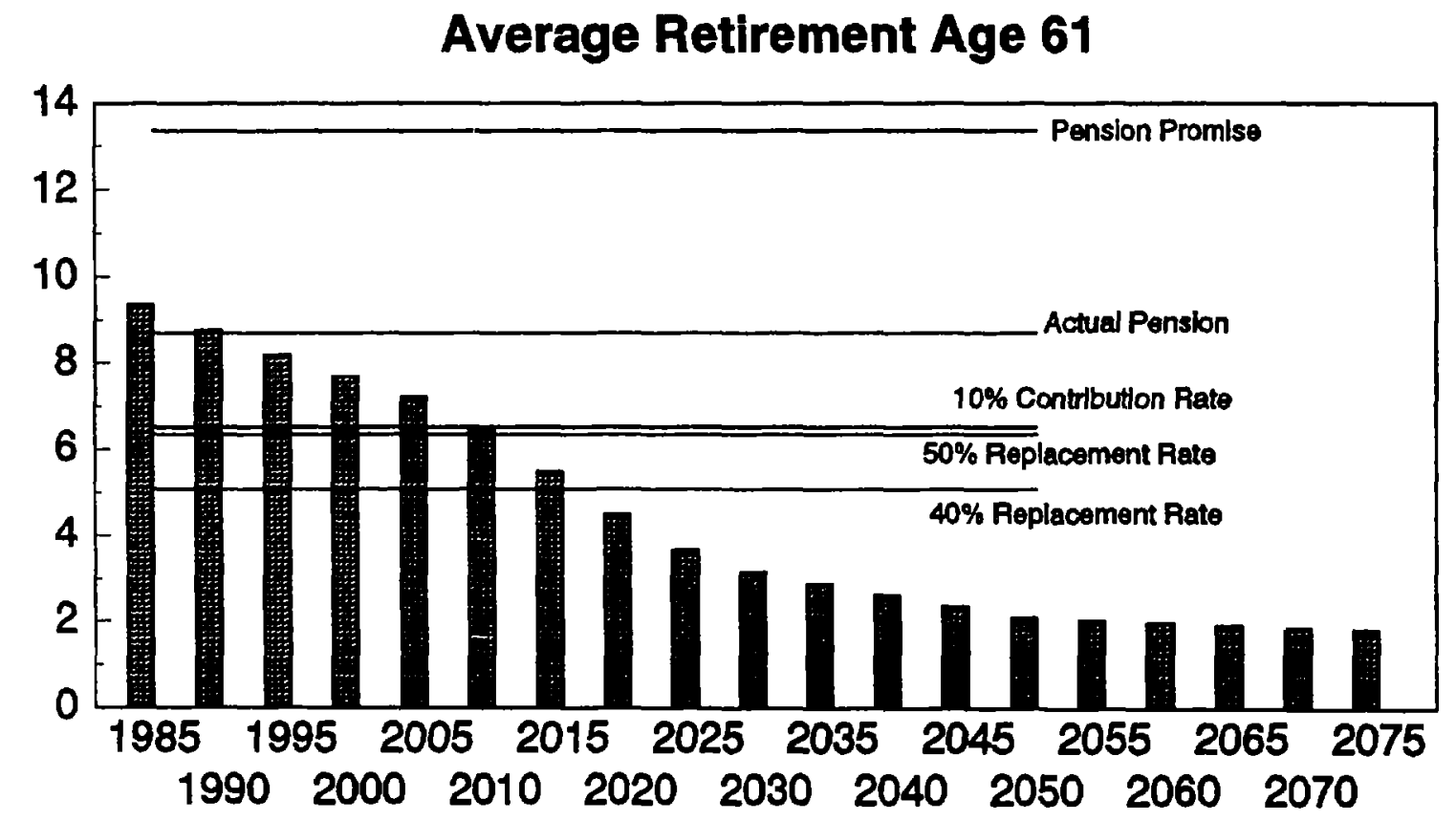

Figure 3

* Decrease the replacement ratio and introduce declining replacement rates with salary: The benefit ratio can be further modified to lower replacement rates explicitly. Ideally, replacement rates should incorporate a constant or increasing accrual rate to reward long service and minimize evasion. Declining 
replacement rates allow lower replacement rates for higher income workers. Decreasing the replacement rate explicitly will also prolong financial solvency, as shown in Figure 3, but again only for a limited period of time. Lowering the pension replacement rate to 50 percent of average wage from the current 68.5 percent allows the system to remain solvent until between 2010 and 2015 . Lowering the pension replacement rate even further to 40 percent of average wage allows the system to remain solvent even longer, until between 2015 and 2020.

* Replace the level amount of maximum pension by a maximum replacement rate for high income workers: This strengthens the link between contributions and benefits and should decrease under-reporting and evasion by high income workers.

* Unbundle health and pension benefits: Health and pension benefits should be separated. Since health costs tend to increase at a much higher rate than pension expenditures as populations age, keeping health and pension benefits together would add to the financial problems in the future. Unbundling will also strengthen the link between contributions and benefits.

* Improve the investment performance of reserves: The reserves should be invested in safe marketable securities at market rates of return. International diversification should be allowed with adequate supervision. A high return on investment reserves would help improve the financial condition of the system.

However, it should be noted that all of the reforms oriented toward maintaining financial solvency are only successful in the short to medium term and will not provide long term security.

\section{D. $\quad$ Radical Reform}

No matter how well designed, defined benefit public pension systems are inherently in conflict due to the redistribution and social insurance objectives. The move to a multi-pillar scheme would solve this dilemma by separating the redistributive and social insurance functions of old age security programs. In this multi-pillar system, the first pillar would be a pay-as-you go public pillar which would have the primary responsibility to redistribute to the old who are lifetime poor. The second pillar which would be a savings pillar, would have the primary responsibility to invest people's savings for old age, through decentralized, competitive but carefully regulated defined contribution schemes based on individual capitalization accounts. Finally, third and fourth pillars would consist of optional but funded companybased or occupational pension schemes and voluntary savings in the form of bank deposits, marketable securities, and investment in real assets.

(i) The public pillar: The objective of redistribution to the old who are lifetime poor clearly requires public management and tax financing. Institutionally, CCSS could be reorganized to manage the public pillar. But there are quite a few decisions to be made in the design of this basic redistributive pillar.

The first issue is that of coverage and benefits. One option is to provide a means-tested benefit only 
to the poor. The big advantage of a means-tested benefit is that for the same expenditure, a larger benefit can be paid, thus enabling more poverty alleviation or lower taxes. Another possibility is to provide universal coverage. A universal flat-benefit pension system will be administratively simple with minimum record-keeping demands. In addition, flat pensions provide some inflation and longevity protection for the entire population of old people. That is, risk diversification is provided for the average person (who will normally contribute to other pillars too). Finally, flat benefits avoid the disincentive to work and save that are inherent in means-tested benefits. For these reasons, flat benefits may be more efficient and will have wider political support than means-tested pensions. Yet another option is what is called "restricted flat" which is a variant of flat pension and covers only a restricted population, usually those who contribute. In situations where fiscal resources do not permit a universal coverage, restricted flat may be the preferred option. It may also be adopted as a transitional measure and its coverage may be expanded as the country's fiscal situation improves. Its major disadvantage is however, that it fails to reach the poorest groups, such as old women or people who have been unemployed for substantial portions of their adult lives. For that reason, it is a weaker poverty-alleviation instrument than universal flat or means-tested benefits. Whatever option is chosen, the benefit should be a minimum but sufficient level necessary for subsistance, and should be provided after the normal retirement age.

The second issue is that of financing. For means-tested or universal flat pensions, the financing should be out of general tax revenue. If a restricted-flat pension is provided, its financing should be out of payroll taxes since only those who contribute are covered. Financing out of general tax revenue, as is the case now, should be avoided if coverage is restricted to active population (or part of it), to prevent redistributions from the poor to the covered. Finally, the system should be pay-as-you-go, and should not accumulate reserves, since public investment performance of reserves is generally quite poor world-wide.

In Costa Rica there is already a non-contributive government-financed system, administered by CCSS, that provides income to the poor regardless of age. The current system can be split, and the old-age part can be re-designed and expanded to create the public pillar.

(ii) The mandatory savings pillar: The second pillar can be a mandatory retirement saving plan, structured as a defined contribution scheme based on individual capitalization accounts. If properly implemented, they are the most effective mechanism to generate savings among workers for income security in their old age. One issue is whether they should be voluntary or mandatory. A mandatory scheme would protect individuals from myopia, the problem that they may not be far-sighted enough to save for their old age. If myopia is common, this would put a strain on the public pillar, in case a meanstested public pillar is adopted. Even in the case of a universal pillar, since the flat benefit will be set at a very basic level, myopic individuals who could have saved during their working life would experience a substantial decline in their standard of living with retirement.

Mandatory savings schemes make benefits directly contingent on contributions plus investment returns and avoid adverse redistributive effects. They are subject to less evasion and cause fewer distortions in labor markets. Their impact on the rate of household and national saving is ambiguous but it is likely to be more positive than that of pay-as-you-go plans. Most important, they have a big impact on the composition of savings in favor of long-term financial assets and have the potential to stimulate the development of modern capital instruments and institutions. 
A major issue in mandatory savings schemes is to avoid giving governments exclusive access to large pension funds and to include incentives for managers to choose the best risk-yield combination of investments. The experience of many countries with centrally managed pension funds is not encouraging in this regard. Governments have spent these funds on public bonds and public enterprise securities, in effect using them as a source of general revenue for consumption rather than productive investment. With interest and principal non-indexed, rates of return become negative during periods of inflation and devaluation.

Decentralized mandatory savings schemes have the potential for attaining much higher investment returns and a more efficient allocation of capital resources. But the danger here is that marketing costs might be high, annuities markets weak, and poor choices of investment managers and investments made by ill-informed workers. Regulations must be enacted and implemented to prevent this from happening. To minimize this risk:

* only prudent companies should be allowed to manage the funds;

* this may include joint ventures with experienced foreign firms;

* $\quad$ investments should be diversified and subject to maximum limits;

* requirements to invest funds exclusively in public securities should be avoided;

* investment in overseas securities should be allowed, especially to reduce exposure to countryspecific risks.

Thus, government involvement is necessary for the second pillar as well as the first. Governments are generally better at providing prudential regulation rather than managing and investing these funds. In Costa Rica, there is a sophisticated off-shore banking system as well as significant non-bank institutions. The population is very well educated. Sufficient human capital exists to enable intelligent investment policies by funds and the development and implementation of effective regulatory rules and institutions. The government is already in the process of developing prudential regulations for recently established voluntary savings schemes. A basic infrastructure for financial regulation of private investors can be developed and strengthened over the next 20 years as capital continues to accumulate. At present, domestic financial sector and the capital market are not large or developed enough to absorb large amounts of capital. However, as demand from the savings pillar starts to increase a variety of indexed debt and equity instruments can be developed. Nevertheless, given that Costa Rica is a small country, in time the pension funds should be allowed to invest a substantial proportion of their reserves internationally.

A basic weakness of the mandatory savings pillar is that it fails to guarantee targeted pension benefits and to protect workers with low wages or interrupted careers. While the use of indexed instruments and international diversification help to insure against major inflation or recession at time of retirement, and regulation of investment options further reduces risk, these measures do not achieve redistributive objectives or alleviate poverty among the old with long-term limited incomes. Thus, in a pension system with multiple pillars and objectives, a mandatory savings scheme can play an important role as one of the main compulsory pillars, but it must be accompanied by a public pay-as-you-go pillar to provide a basic benefit. 
(iii) Optional company-based or occupational pillar: The third pillar could consist of optional but fully-funded company-based pension schemes that would seek to offer additional supplementary benefits. Such schemes can be offered by large companies, including multinational corporations operating in Costa Rica (such as that offered by Coca Cola). These schemes often aim to encourage firm loyalty and firm specific training, and tend to limit labor mobility. Company-based schemes need to be regulated to ensure equitable treatment of all employees and safety of their investment assets. Another possibility is occupational defined contribution plans. In Costa Rica, the new capitalized teachers plan and other special regimes could be restructured as voluntary, fully-funded, defined contribution plans. However, the role of both company-based and fully-capitalized occupational schemes would be very limited given a second pillar as described above. Indeed, since regulation of these schemes is inevitable and since the burden of guarantees is eventually passed on to the public treasury in any event, a national mandatory saving scheme is superior to fragmented occupational schemes, on grounds that it minimizes labor market distortions and maximizes coverage and equity.

(iv) Voluntary savings pillar: Finally, the fourth pillar would consist of voluntary savings in the form of bank deposits, life insurance policies and annuities, marketable securities and investments in real assets, such as owner-occupied housing. The role of voluntary savings would depend on the role of the other pillars, especially the size of two compulsory pillars and on their relative fiscal treatment.

Both voluntary savings plans and occupational pension plans tend to cover high income workers disproportionately. Voluntary plans have the advantage that they do not distort labor market mobility. Moreover, they allow individuals to determine the amount of contributions as well as the choice of investment policies. They have the disadvantage that myopic workers may not save enough, even when tax advantages are granted. Also, those who save may not invest it wisely; studies of saving behavior of workers suggest that their investment policies are too conservative and do not provide high yields. This is why multi-pillar pension system consisting of a public pillar, a national mandatory savings scheme with regulated investment choices, and a voluntary savings pillar which provides the possibility of modest taxadvantaged voluntary add-ons is preferable both to fragmented occupational plans and purely voluntary plans complemented with the public pillar.

\section{E. Choosing Between Different Reform Options}

In choosing between the various reform options, it is important to consider the costs of the various alternatives. The first alternative is to do nothing in the way of substantive reform. The second alternative is to enact limited reform, such as raising the retirement age to 65 . The third alternative is to implement radical reform, consisting of the flat universal pension, complemented by a mandatory savings scheme. Table 8 summarizes the costs of the various options.

\section{Table 8}

Costa Rica: Present Value of Government Costs, 1993-2075, under Different Reform Options (billion 1992 colones) 


\begin{tabular}{|c|c|c|c|c|c|}
\hline OPTION & UNIVERSAL & $\begin{array}{l}\text { MEANS } \\
\text { TESTED }\end{array}$ & CCSS & $\begin{array}{l}\text { SPECIAL } \\
\text { REGIMES }\end{array}$ & TOTAL \\
\hline \multirow{2}{*}{ No Reform } & & \multirow{2}{*}{142.9} & $\begin{array}{r}\text { a. Promise } \\
3629.9 \\
\end{array}$ & \multirow{2}{*}{2904.7} & $\begin{array}{r}\text { a. Promise } \\
6677.5\end{array}$ \\
\hline & & & $\begin{array}{r}\text { b. Current } \\
1717.6 \\
\end{array}$ & & $\begin{array}{r}\text { b. Current } \\
4765.2 \\
\end{array}$ \\
\hline \multirow{2}{*}{$\begin{array}{l}\text { Limited } \\
\text { Reform }\end{array}$} & & \multirow{2}{*}{142.9} & $\begin{array}{r}\text { a. Promise } \\
2512.6\end{array}$ & \multirow{2}{*}{2218.5} & 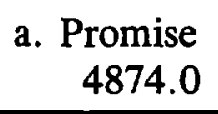 \\
\hline & & & $\begin{array}{r}\text { b. Current } \\
1051.9\end{array}$ & & $\begin{array}{r}\text { b. Current } \\
3413.3 \\
\end{array}$ \\
\hline $\begin{array}{l}\text { Radical } \\
\text { Reform }\end{array}$ & 1911.9 & & $\begin{array}{r}\text { Transition } \\
1037.3\end{array}$ & $\begin{array}{r}\text { Transition } \\
1607.4\end{array}$ & $\begin{array}{c}4556.6 \\
-\quad 56.0 \\
4500.6\end{array}$ \\
\hline
\end{tabular}

Under the no reform option, the costs to the government consist of three types. First, the current system provides some means tested pensions for the extremely poor elderly at government expense. The present value of these costs from 1993 to 2075, using the simulation model presented in the Annex, is around 142.9 billion colones. Second, the CCSS system entails two types of costs on the government, the 0.25 percent of the covered wage base which is the government's contribution and the shortfall which the system will face if no reform takes place, implying no change in retirement age, contribution rate, or benefit rate. Assuming that the pension is fully inflation indexed and that individuals who work 43 years, from age 18 to 60 , receive the 83 percent of their highest years' salary that they have been promised, the simulation model projects that the present value of the combination of these two costs for CCSS will amount to 3629.9 billion colones. Taking the more conservative approach that the government will choose to allow inflationary erosion of pensions and setting the benefits at their 1985-91 average level, the costs come down considerably to 1717.6 billion colones. The government could continue to lower costs by further eroding the purchasing power of pensions. However, this would result in severe consequences on the purchasing power of the elderly, many of whom are receiving close to the minimum pension already. Third, the final element of government costs arises from the special regimes. With very little data on their operations, we can make only rough calculations based on CCSS data as to how fast their costs will rise. The present value estimate is calculated at 2904.7 billion colones. This is probably an underestimate since the 1993 projected value is 25 percent lower than the actual 1993 value. However, the sum of all these costs come to 4765.2 billion colones under the inflation erosion option and 6677.5 billion colones under the promised pension option.

Under the limited reform option, where the retirement age is raised to 65 years immediately, we use similar methods to estimate costs. While the cost of the means tested pension remains the same since its qualifying age was already 65 years, the costs of both the CCSS and special regimes falls considerably. Under the full promised pension, the present value of costs associated with CCSS fall to 2512.6 billion 
colones. Under the inflation reduced pension, the present value of costs fall to 1051.9 billion colones. The extremely rough estimate of special regimes costs under the assumption that the retirement age is raised to 65 for these individuals as well is about 2218.5 billion colones. However, as the system changes, some transition costs will be incurred. For example, if the retirement age changes to 65 today, the 62 year old already retired will generally not be forced to return to the labor force, but will continue to receive benefits. Under the extremely conservative assumption that only the currently retired who are below the new retirement age will receive early benefits and that the new retirement age will be implemented immediately, the government would incur an additional 13 billion colones in transitional costs. The total costs under limited reform will thus be 4887.1 billion colones if the pension promise is fully upheld and 3426.4 billion colones if the average level of inflation erosion from the past is allowed to continue. Again, any phasing in or more generous transition toward the new retirement age will raise transition costs significantly.

The third alternative is the radical reform. The radical reform costs consist primarily of two components: cost of the universal flat pension and transition costs. The radical reform option evaluated here gives all individuals aged 65 or older a flat pension with the benefit set at 50 percent of the minimum wage. Because all individuals will receive this flat benefit, the means tested noncontributory program which currently exists can be eliminated. The present value of the cost of providing this benefit to all individuals from 1993 to 2075 is estimated to be 1911.9 billion colones. The transition costs arise from an extremely generous transition mechanism in which all individuals who are current CCSS members, either as beneficiaries or as contributors, will be allowed to remain in the system making the same contributions as today, will retire at the current retirement age, and will receive the current level of benefits until they die. These individuals, however, will not receive the universal flat pension mentioned above. These provisions are generous even with respect to the limited reform option in that all members of the current system can retain their current retirement age. The government costs associated with retaining current CCSS members is estimated to be 1037.3 billion colones. Note that this is cheaper than continuing the current system because the huge cost increases projected for CCSS begin when the current 20 year olds retire. Since many of the current 20 year olds are not in CCSS yet, the government will save substantially by keeping these new workers in the new system. The extremely rough estimate of providing a similar transition package for the participants of the special regimes is about 1607.4 billion colones. The combined cost of radical reform thus ends up about 4556.6 billion colones. Since the CCSS currently has a surplus of 56 billion colones which could be used to reduce costs, the net cost would be around 4500 billion colones.

Thus, while the radical reform appears cheaper than the no reform option, the limited reform, allowing the current level of inflation erosion, appears cheaper than radical reform. However, several additional factors need to be considered. First, a large chunk of the costs involved in the radical reform are the transition costs. Looking at the year 2075, the annual cost of the limited reform will be roughly 233.6 billion 1992 colones, while the annual cost of the radical reform will be only 138 billion colones. Assuming that GDP/worker remains roughly constant, pensions under the limited reform with the current level of inflation erosion will cost the government 14.6 percent of GDP, while pensions under the radical reform will cost the government 8 percent of GDP. If GDP growth accelerates, both numbers will fall, but the annual cost of the radical reform pensions will always be smaller. It is highly likely that the economy will not be able to afford the high cost of the pensions under the limited reform and will be forced to undertake additional reforms which will reduce benefits or raise contribution rates to the detriment of future 
generations.

A second consideration is the increase in overall benefits and potential poverty alleviation involved in the radical reform option. The flat benefits suggested are 50 percent of the minimum wage paid to all individuals. Currently only around half of the working population and less than a third of individuals aged 18-60 (working or not) are covered under any pension scheme. The radical reform involves a massive increase in coverage and a resulting decline in old age poverty. Furthermore, many families have at most one covered worker. Since the average pension paid by CCSS is close to the minimum pension of 80 percent of minimum wage, the average family receives a little more than 80 percent of minimum wage. Under the radical reform, each elderly family member, husband and wife, will receive 50 percent of the minimum wage, for a combined family total of 100 percent of the minimum wage. The means tested pension currently pays about 12.5 percent of minimum wage. These individuals would be receiving 50 percent of minimum wage. Plus, current workers will also receive benefits based on their own mandatory savings. Thus, the welfare level of current pension recipients will in fact be higher than under the current system. While the costs for radical reform appear higher than for limited reform, the benefits are markedly higher as well. One approach to lowering the costs of radical reform would be to lower the benefits somewhat.

A third consideration takes into account spillover benefits which occur as a result of radical reform. The incentive for manipulating wages and employment records as well as employment itself to reduce contributions would be eliminated. Eliminating evasion would make the labor market more efficient and eliminate the wastage involved in evasion. Generally, the move from pay as you go pensions to fully funded mandatory savings pensions will generate savings for the economy. This additional saving can be invested and will contribute to growth in the economy. Finally, the current CCSS surplus funds are invested in such a way that they historically have generated little real return in an economy where the real rate of return on other assets has been positive.

To summarize, the above simulations illustrate the urgency of reform by showing that the "no reform" option is the costliest alternative the government can choose. Limited reform option appears less costly than a radical reform, however, it simply delays problems rather than really solving them once and for all. While radical reform may be the costlier reform option - mostly due to the very conservative transition process we have assumed - its benefits are markedly higher as well. 


\section{References}

Caja Costarricense del Seguro Social, Anuario Estadistico, 1992.

Caja Costarricense del Seguro Social, Departamento Actuarial, Inversiones de la Reserva del Seguro de Invalidez, 1992.

Costa Rica Indicadores de Seguridad Social 1988-1992.

Costa Rica Departamento de Estadistica Seccion, Estadisticas de Seguridad Social, Anuario Estadistico, 1991.

Vittas, Dimitri and Michael Skully, "An Overview of Contractual Savings Institutions," World Bank, PRE working papers, No. 605, March 1991.

World Bank, The Old Age Security Report, Washington D.C., 1994. 


\section{Annex}

\section{A. Basic Simulation Model}

Figure 1 is based on a simulation model which calculates the required worker per retiree ratio to maintain solvency in the CCSS scheme. Workers are assumed to begin work at age 18, earning the real minimum wage, based on 1992 data, and work until age 61, the average age of retirement. The average lifetime wage is assumed to be the 1992 real economy wide average wage. With both a fixed starting wage and a fixed average wage over a fixed number of working years, the model generates an average annual wage growth, which can be used to calculate a final salary. Since the CCSS pension benefit is based on final salary, the average pension in real terms is calculated by multiplying the promised replacement rate by the final salary. The actual average pension, 1985-91, is already expressed as a percentage of average wage and is calculated by multiplying the average wage by the average actual replacement rate. The average contribution is calculated by multiplying the contribution rate by the average wage. The average pension is then divided by the average contribution to determine the number of contributors required to fund each pensioner. The model is modified slightly to take into account the modest real wage growth that Costa Rica has experienced since 1983, which raises contributions, but not benefits.

Table 6 uses the same simulation model and assumptions, but instead of solving for the worker to retiree ratio, uses the demographic projections from the World Bank Population Projections and the actual replacement rate to solve for the required contribution rate. The second line uses the actual demographic projections and the actual contribution rate to solve for the resulting replacement rate as a percentage of the economy wide average wage.

Figures 2 and 3 rely on the same simulation model with modifications reflecting the differing assumptions presented in the text. In Figure 2, the model calculates the required number of workers to retirees taking into account that workers work an additional 4 years. This modification has the effect of raising the economy wide average wage slightly. Figure 3 shows the results of changing contribution rates or replacement rates.

\section{B. Calculation of Costs}

\section{No Reform Option}

Under the no reform option, the costs to the government consist of three types. The first component is the current means tested pension. The expenditure on the elderly, those aged 65 and above, is taken out of the total 1992 means tested pension spending. This annual expenditure is assumed to grow proportionately with the number of elderly as compared to the number of elderly in 1992 . The present value of these annual expenditures are then calculated using a 2 percent real interest rate and summed. 
The second cost arises from the CCSS system and can itself be divided into two components: (1) the cost of the annual 0.25 percent of total covered wages while the system remains solvent, and (2) government funding to cover the shortfall once the system becomes insolvent. The annual cost of the government contribution is calculated by first computing an annual wage base and then multiplying it by the government's contribution rate. The annual wage base is calculated by increasing the current 1992 wage base proportionately by the projected number of individuals aged 18 to 61 in each year relative to the number in 1992.

The second component of the CCSS costs involves covering the shortfall once the system becomes insolvent. The annual funding shortfall is calculated by calculating the required contribution rates to maintain system solvency as described in part $\mathrm{A}$ and taking the difference between those and the actual contribution rate and multiplying that difference by the annual wage base. Initially this shortfall is assumed to be covered by the current surplus. Once the surplus is exhausted, the shortfall is passed to the government budget, generating additional annual costs.

The present value of the annual costs of these two CCSS components are calculated and then summed from 1993 to 2075 . The real interest rate used for the present value calculations is a real 2 percent.

The third type of cost arises from the Special Regimes. With little information available on the Special Regimes, the annual expenditures were calculated by taking the 1992 annual expenditures and increasing them proportional to the annual increase in the population aged 61 and above. The annual revenues are calculated by taking the 1992 revenues and increasing them proportional to the annual increase in the working age population. The difference is the annual government cost of the Special Regimes. This method clearly underestimates the true costs since the actual numbers for 1993 costs exceed the projected costs by more than 25 percent.

\section{Limited Reform Option}

The same calculations were repeated with the modification that the workers were assumed to continue working until age 65 . The increase in working years increases the wage base in 1992 . The required contribution rate is also affected as noted in part $A$ and in the figures, affecting the calculated shortfall. The assumption used was that the retirement age jumps immediately to age 65 in 1993 . To the exent that individuals aged 63 in 1993 and who are already retired are not forced to give up a pension and return to the labor force, the costs will rise somewhat.

\section{Radical Reform Option}

Radical reform consists of two types of costs. The first arises from the universal pension which will be offered to everyone regardless of labor force participation. These costs are calculated by multiplying the number of people aged 65 or older by the universal pension annually. The total number of people aged 65 
or older is reduced by the number of participants in the old CCSS system based on detailed information on CCSS participants by age.

The transition costs arise because individuals who currently belong to either the Special Regimes or CCSS as either beneficiaries or contributors are allowed to remain in the system. Current contributors to CCSS, are expected to continue contributing to age 61 and will collect benefits until age 80 . Current beneficiaries are expected to continue collecting benefits until age 80 . The present value of the total future contributions to CCSS is subtracted from the present value of the total future benefits to be paid by CCSS. The difference is considered the transition costs. An extremely rough estimate of Special Regime transition costs was calculated by computing the ratio of current CCSS costs to transition costs and using that ratio and current Special Regime costs to calculate Special Regime transition costs. 



\section{Policy Research Working Paper Series}

\section{Title}

WPS1464 How Does the North American Free Trade Agreement Affect Central America?

WPS1465 Post Trade Liberalization Policy and Institutional Challenges in Latin America and the Caribbean

WPS1466 Ownership and Financing of Infrastructure: Historical

Perspectives

WPS1467 Beyond the Uruguay Round: The Implications of an Asian Free Trade Area

WPS1468 Government's Pole in Pakistan Agriculture: Major Reforms are Needed

WPS1469 The Role of Labor Unions in Fostering Economic Development

WPS1470 Pension Systenis and Reforms: Country Experiences and Research Issues

WPS1471Pension Reform and Growth

WPS1472 Fiscal and Monetary Contraction in Chile: A Rational-Expectations Approach

WPS1473 The Surge in Capital Inflows to Developing Countries: Prospects and $P$ Policy Response

WPS1474 Are Stable Agreements for Sharing International River Waters Now Possible?

WPS1475 Decentralization: The Way Forward for Rural Development?

WPS1476 Public Spending and the Poor: What We know, What We Need to Know

WPS1477 Cities Without Land Markets: Location and Land Use in the Socialist City
Author

Date

Contact for paper

Edward E. Leamer Alfonso Guerra

Martin Kaufman

Boris Segura

Sarath Rajapatirana

May 1995

J. Troncosio

37826

Charles D. Jacobson Joel A. Tarr

June 1995

WDF

31393

Jeffrey D. Lewis

Sherman Robinson

Zhi Wang

Rashid Faruqee

June 1995

June 1995

Patricio Arrau

June 1995

Klaus Schmidt-Hebbe!

Giancarlo Corsetti

K.laus Schmidt-Hebbel

June 1995

Klaus Schmidt-Hebbel

June 1995

Luis Serven

Eduardo Fernandez-Arias

june 1995

Peter J. Montiel

D. Marc Kilgour

June 1995

Ariel Dinar

Andrew N. Parker

June 1995

June 1995

June 1995

Alain Bertaud

Bertrand Renaud
C. Anbian

81275

WDR

31393

B. Kirn

824i;

E. Khine 37471

E. Khine 37471

E. Khine 37471

C. Spooner 32116

D. Housder: 36637

C. Bernardo 37699

L. Lewis 30539 


\section{Folicy Research Working Paper Series}

Title

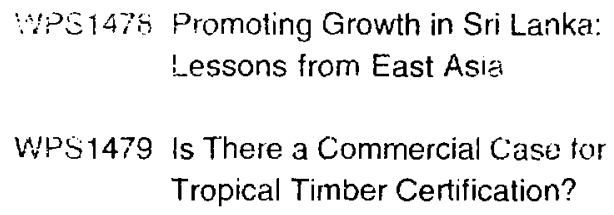

WPS1480 Debt as a Control Device in Transitional Economies: The Experiences of Hungary and Poland

Wes 1481 Corporate Control in Central Europe and Russia: Shouid Banks Own Shares?

WPS1482 A Measure of Stock Market Integration for Developed and Emerging Markets

NPS1483 Costa Rican Pension System: Options for Reform
Author

Sadiq Ahmed

riva Ranian

Panayotis N. Varangis

Rachel Crossiey

Carlos A. Primo Braga

Herbert L.. Baer

Cheryl W. Gray

Peter Dittus

Stephen Prowse

Frobert A. Korajczyk

Asli Demirgüç-Kunt Anita Schwarz
June 1995

Date

June 1995

June 1995

June 1995

June 1995

June 1995
Contact for paper

A. Bhaila 82168

J. Jacobson 33710

G. Evans 85783

G. Evans 85783

P. Sintim-Aboagye 38526

P. Sintim-Aboagye 38526 